\title{
Mandatory audit firm rotation and audit costs: A survey of auditing firms in Bahrain
}

\author{
Kousay M. Said*, Hussein Ali Khasharmeh \\ Department of Accounting, College of Business Administration, University of Bahrain, Kingdom of Bahrain
}

Email address:

said1.kousay@gmail.com (K. M. Said), hkhasharmeh@hotmail.com (H. A. Khasharmeh)

\section{To cite this article:}

Kousay M. Said, Hussein Ali Khasharmeh. Mandatory Audit Firm Rotation and Audit Costs: A Survey of Auditing Firms in Bahrain. Journal of Finance and Accounting. Vol. 2, No. 6, 2014, pp. 116-128. doi: 10.11648/j.jfa.20140206.11

\begin{abstract}
The Purpose of this paper is to ascertain the perceptions of audit firms on the vexed issue of mandatory rotation of auditors in kingdom of Bahrain. A hand administered questionnaire survey of 102auditors, and accounting professionals was undertaken. Descriptive statistics were used to find out the most common reasons why respondents were agreed or disagreed with the idea of introduction of mandatory rotation of auditors in Bahrain and its effects on audit costs. The findings of the study indicate that there is an association between mandatory rotation of audit firms and audit costs. Analyses of variance (ANOVA) were also conducted to test the possibility of confounding effects arising from participants' background and experience. None of these variables were found to have a confounding effect on the experimental results. The results also reveal that the adoption of rotation rules wasn't given enough attention among the auditing firms in Bahrain. Finally, this study contributes to global debate on mandatory rotation of auditors from the view point of an emerging economy.
\end{abstract}

Keywords: Mandatory Audit Firm Rotation (MAR), European Commission (EC), Government Accounting Office (GAO), Audit Costs, Gulf Cooperation Countries (GCC), Company Accounting Oversight Board (PCAOB)

\section{Introduction}

The concept of mandatory audit rotation (MAR) is not new. There has been considerable interest in MAR as a means of reducing the incidence of audit failure, reducing the cost of audit and protecting investors and other users of financial statements. Mandatory audit firm rotation sets a limit on the number of years a public accounting firm may audit a company's financial statements. After a predetermined period, an accounting firm is no longer eligible to serve as the company's auditor for a set time interval and a rotation of firms is required. A mandatory audit rotation rule which sets a limit on the maximum number of years on audit firm can audit a given company's financial statements has been proposed as a means to increase investors' confidence in financial reports.

In the US, the Government Accounting Office (GAO), which was delegated by the Securities European Commission (SEC) to study the issue of MAR, concluded that there is no clear evidence regarding the potential benefits of a MAR rule (GAO, 2008). However, more recently the Public Company Accounting Oversight Board (PCAOB) issued a concept release (PCAOB, 2011), in which the Board solicits public comments on the advantages and disadvantages of mandatory audit firm. Horwath (2012) pointed out that 94\% of the comment letters received by the PCAOB were against rotation.

Mandatory audit firm rotation would require the clients to replace their external auditor at a certain time, usually after a few years. Section 207 (C) of Sarbanes Oxley Act (SOA) define the term "mandatory rotation" as the imposition of a limit on the period of years on which a particular registered public accounting firm may be the auditor of record for a particular issuer.

In December 2011, the American Institute of Certified Public Accountants (AICPA) issued a comment letter that the PCAOB refrain from imposing mandatory audit rotation.

Whether audit firm rotation should be made mandatory is an issue that has been debated for almost five decades in the US and around the world (Kwon et al., 2010).

Proponents of mandatory audit firm rotation have argued that a new auditor would bring to bear greater skepticism and a fresh perspective that may be lacking in long-standing auditor-client relationship. The proponents added that when a company has been a client of an audit firm for a number of years, the client can be viewed as a source of a perpetual 
annuity, potentially comparing the auditor's independence.

According to Price Waterhouse (2012), mandatory audit rotation will reduce audit and financial reporting quality. Mandatory audit firm rotation would make financial reporting less reliable, and add cost for investors.

It was suggested in the literature that mandatory audit rotation is costly and disruptive and could undermine audit quality. The GAO (2003) study on mandatory audit firm rotation estimated increased initial audit cost of more than $20 \%$ (some studies in Europe suggest 40\%) and this did not include costs incurred by the audit committee and management to conduct the tendering process. The cost of mandatory firm rotation may also be compounded due to a company's particular circumstances. For example, changing an auditor in the midst of a major business transaction or merger could be complicated and costly.

In order to get and retain clients, the auditor charges lower fees in the early years of audit engagement. The audit fees will increase as the audit engagement become longer.

However, opponents of mandatory firm rotation have argued that MAR would be costly and counterproductive and ineffective in improving audit quality because the auditor would lack familiarity with the client and its industry (AICPA, 1992). Furthermore, opponents have pointed to a higher incidence of problem audits in the early years of the auditor-client relationship than in the later years (Pierre St. and Anderson, 1984).Kwon et al., ((2010) concluded that mandatory audit firm rotation increases the cost of the audit firms and clients while having no discernible positive effect on audit quality. Mandatory rotation will almost certainly force management to learn to do things differently in working with a new audit firm. There will be IT cost, process costs, training costs and losses of efficiency as the two team's first start to interact (Breeden 2012).

Thus, based on the above discussions, the problem statement of the study can be highlighted from the point that the audit function is to provide reliable financial information to the interested users such as shareholders, creditors, lending institutions and others for decision making. The users must be confident in relying on the financial information. However, a number of recent corporate reporting failures such as Enron and WorldCom have raised concerns over the credibility of financial information.

The significance of the current study is to survey current audit appointment practices by auditing firms in Bahrain and evaluates their perceptions on the potential effects provided by implementing mandatory audit firm rotation requirement (audit costs). To the best of the authors' knowledge, this is the first exploratory survey conducted in Bahrain. It is hoped that the study will provide some viewpoints of the interested parties in determining whether audit firm rotation should be mandated in Bahrain, and to contribute to the international debate about the requirement that some companies have to rotate their independent auditors periodically.

Thus the current study aimed to explore whether mandatory audit firm rotation should be implemented in Bahrain considering that some countries have had good experience such as in Italy. This study investigated the potential effects of such a requirement on related party "auditing firms" in Bahrain.

Specifically, the objectives of this study are:

1. To explore current audit appointment practices by auditing firms in Bahrain.

2. To look into the opinion of auditing firms in Bahrain on potential effects provided by implementing mandatory audit firm rotation (audit costs).

3. To investigate their views in implementing mandatory audit firm rotation in Bahrain.

By attaining such objectives, the current study is expected to contribute to the literature on the following issues:

1 To fill the gap in the existing economics of auditing literature since there is little published research papers directly testing mandatory audit firm rotation in developing countries and specifically GCC countries such as Bahrain.

2 To the best knowledge of the researchers, it is the first study that explicitly examines the relationship between mandatory audit firm rotation and audit costs in Bahrain.

3 This study has useful implications for regulators, members of the accounting profession, and financial statement users as they deliberants on the costs and benefits of mandatory audit firm rotation.

The remainder of the study proceeds as follows: Section 2 provides a review of the controversy and literature review about mandatory audit firm rotation and audit costs. Section 3 provides for Bahrain auditing environment. Section 4 provides for methodology (data collection, population of the study and testing hypotheses). Section 5 presents the statistical analysis and findings of the study. Section 6 highlights the conclusions and recommendations.

\subsection{Objectives of the Study}

The main objective of the study is to explore whether mandatory audit firm rotation should be implemented in Bahrain, and the effects of such a requirement on audit costs and fees. In order to achieve this objective, the following research sub objectives have been developed:

1. To explore current audit appointment practices by listing companies in Bahrain.

2. To reveal the perceptions of auditing firms in Bahrain on potential effects provided by implementing mandatory audit firm rotation.

3. To investigate auditing firms' views in implementing mandatory audit firm rotation in Bahrain.

\subsection{Significance of the Study}

The significance of the current study evolved for a number of reasons.

1 Most of the literature on audit firm rotation focuses on developed countries. The current study, therefore, addresses this issue in developing countries, the case of Bahrain.

2 As far as the current researchers are aware, no such 
study was carried out with special reference to Bahrain. The results of the study are hoped to increase knowledge about how listed companies and audit firms in Bahrain reflect mandatory audit rotation through their reporting practices.

3 Because Bahrain is a member of GCC countries, they share a number of specific structural economic features. Key common features of GCC countries are: a high dependency on oil as expressed in the share of oil (and gas) revenues in total fiscal and export revenues; young and rapidly growing national labor forces; and the heavy reliance on expatriate labor in the private sector. In addition, listed companies are subject to similar reporting requirements. The companies' laws in these countries require all legal entities to submit an annual report which includes a director's report, auditor's report, and financial statements, and to have their accounts prepared in accordance with International Financial Reporting Standards issued by the International Financial reporting Standards. Thus, GCC countries are expected to benefit from the results of the current study.

It is believed that this study would supplement literature by providing answers to the following research questions:

RQ1: In terms of audit costs, what effects do practicing audit engagement partners perceive result from mandatory partner rotation?

RQ2: In terms of audit costs, is there any relationship between auditors' background variables (such as position, qualification, experience, age, and type of respondents) and their perceptions of mandatory partner rotation?

\section{The Bahrain Auditing Environment}

Some important features of the audit market in Bahrain must be understood to perceive the context in which this study was undertaken.

As of the end of February 2014, audit services in Bahrain are provided by 25 accounting firms. Five of these are considered local; four are operating as foreign branches; and the remaining are linked to international firms. The Big Four; i.e., Ernst \& Young (E\&Y), Deloitte \&Touche (D\&T), KPMG, and Price Water House Coopers (PWC) have a strong presence in Bahrain. D\&T and KPMG operate as a joint venture, whereas the other two operate as branches of international firms. BDO Jawad Habib and E\&Y are the only two firms registered with the United States (US)

The Central Bank of Bahrain (CBB) requires financial institutions to be audited by one of the big audit firms. Audit services are regulated by the Amiri Decree Number 26 of 1996, which requires auditors to obtain a license to practice and set the minimum requirements for a license. In effect, audit firms got two licenses, one to practice auditing and the second specifically to offer auditing services to financial institutions.

Appointments of auditors, as per article (205) paragraph (e) of the Bahrain Commercial Companies Law Number 21 of
2001, should be made on a yearly basis at firm's annual stockholder meetings. However in practice, boards of directors are empowered by annual meetings to appoint auditors and to determine their remuneration. This practice is subject to criticism on the grounds that an auditor's role is to mitigate agency problems that might exist between the board and the shareholders.

The CBB's authority is based on article, (61) paragraph (a), of The Central Bank of Bahrain and Financial Institutions Law Number 64 of 2006, which states: "Every Licensee shall appoint one or more qualified and experienced external auditors for its accounts for every financial year. Prior written approval by the Central Bank will be required before appointing an auditor." This approval is needed annually. In cases where in a decision has been taken to replace the external auditors before the end of the year, the respective financial institutions are also required to inform the $\mathrm{CBB}$ about the reasons for this decision.

Auditors and Accounting Standards Module was first issued in October 2010 under otherwise excepted by the Central Bank of Bahrain (CBB). Specialized licensees must ensure that the audit partner responsible further audit does not undertake that function more than 5 years in succession. For purpose of Paragraph AA-1.3.1, the first 5 year period referred to as for period ending December 31, 2010. Specialized licensees must notify by CBB of any change in audit partner.

Auditors appointed by specialized licensees must be independent (CF sections AA-1.4 and AA-1.5). Auditors who resign or are otherwise removed from office are required to inform the $\mathrm{CBB}$ in writing of the reasons for the termination of their appointment (Sections AA-1.2).

The appointment of auditors normally take place during the course of the firm's annual general meeting, specialized licensees should notify the $\mathrm{CBB}$ of the proposed agenda. The CBB's approval of the proposed auditor does not limit in any way shareholders rights to subsequently reject the board choice. The $\mathrm{CBB}$ is considering the proposed (re) appointment of an auditor, takes into account the expertise, resources and reputation of the audit firm, relative to the size and complexity of the licensee. Specialized licensees must notify the $\mathrm{CBB}$ as soon as they intended to remove their external auditor. Specialized licenses must ensure that the replacement auditor is appointed (subject to CBB approval), as soon as reasonably practicable after a vacancy occurs, but no later than three months.

According to Article AA-1.2.3, the external auditor of specialized licensees must inform the CBB in writing, should it resign or its appointment as auditor be terminated, within 30 calendar days, of the event occurring, setting out the reasons for the resignation or termination.

Article AA-1.3.1 states that unless otherwise exempted by the CBB, specialized licensees must ensure that auditor partner responsible for their audit does not undertake that function more than five years in succession.

Article 61 (d) of the CBB law imposes conditions for the auditor to be considered as independent. Before a specialized 
licensee appoints an auditor, it must take responsible steps to ensure that the auditor has the required skills, resources and experience to carry out the audit properly, and is independent of the licensee.

For an auditor to be considered independent, it must, among things, comply with the restrictions in Section AA-1.5 In that, specialized licensees must not provide regulated services to their auditor.

Article 217 prohibits an auditor from (1) being a chairman or a member of the board of directors of the licensee he audits. (2) Holding any managerial position in the licensee he audits. (3) Acquiring any shares in the licensee he audits, or selling any such shares he may already own, during the period of his audit. Furthermore, the auditor must not be a relative (up to the second degree) of a person assuming management or accounting duties in the licensee.

These arguments may be applied and/or linked to Bahrain. In the light of the increasing focus on the stock exchange market of Bahrain as important avenue for attracting foreign investments and to encourage local residents to invest in shares, Bahraini companies may engage in mandatory audit firm rotation as a mean to enhance the quality of audit. And this will help to enhance the company's ability to raise capital at the lowest cost possible (Healy and Palepu, 1993; Lev, 1992).

In Bahrain, it is not mandatory to switch audit firms. In fact, in 2006, the $\mathrm{CBB}$ took a position against a motion in the parliament to mandate such a requirement on the ground that small markets are distorted by such decisions. Experience has shown that switching of audit firms takes place in very rare cases and generally occurs only after an audit failure. The CBB does require auditors of financial institutions to switch auditing partners at least every five years. Auditing firms claim that they follow such a practice for other firms in accordance with their own internal policies. Auditors are not prevented from joining a client firm at any time, even immediately after formulating an audit opinion.

\section{Literature Review and Hypotheses Development}

Regulators are in agreement about the general cost drivers of mandatory audit firm rotation, such as set-up costs of the new auditors to understand the client's business model and organizational structure, as well as costs of the client's management to support the new auditors in these learning procedures (PCAOB, 2011; European Commission, 2011a). This conjecture is confirmed by South Korean research examining mandatory audit firm rotation (Kwon et al., 2010). The PCAOB currently discusses cost increases of $20 \%$ of the audit costs due to audit firm rotation. At the same time, rotations are often used for negotiating lower average costs per hour of audit work, as shown in the Italian mandatory audit firm rotation environment (Barton, 2002). Such price competition and the subsequent downward pressure on audit fees are particularly feared by auditors (KPMG International, 2010; IDW, 2012b; Ernst \&Young, 2011). Meanwhile, investors have repeatedly expressed willingness to bear some added costs if the result is a better audit (CFA, 2011). For instance, prior studies document that investors pay a larger premium for 'high-quality' earnings, assuming that those earnings are sustainable (Teoh \& Wong, 1993; Schipper \& Vincent, 2003). Focusing on audit clients, 38\% of Certified Public Accountants and $65 \%$ of the Fortune 1000 company survey respondents acknowledged that investor perceptions of auditor independence would increase under mandatory audit firm rotation, even though the costs of mandatory audit firm rotation would ultimately exceed the benefits (United States General Accounting Office, 2003 and 2004).

Regulators in particular expect positive financial market reactions due to increased audit quality and positive perceptions of 'independence in appearance' (Shockley, 1981; Elliot, 2000; Dopuch et al., 2001; European Commission, 2011b). More specifically, regulators argue that the costs of mandatory audit firm rotation will be significantly less than the costs endured by investors losing confidence in financial statements (Conference Board Commission, 2008). Overall, regulators assume that mandatory audit firm rotation might prevent large-scale corporate collapses (Jackson et al., 2008) and damages to audit firms. This is based on the assumption that a loss of reputation due to audit failures may significantly reduce the present value of future revenue streams from both audit and non- audit services (Krishnan \& Krishnan, 1996). Aside from the proposed positive effect on audit quality, rotation might also strengthen the reliability of financial information, which in turn should directly reduce costs of capital (for example, in a general context of costs of capital, Jensen \& Meckling, 1976; Watts \& Zimmerman, 1986).

Table 1 summaries archival studies examining costs and benefits of mandatory audit firm rotation. Archival research generally supports a negative impact of audit firm tenure on the cost of companies' capital. Mandatory audit firm rotation leads to an increase of total auditing costs (Copeland 2002; Melancon 2002). It will lead to an increase of total costs for both the auditors and companies. It will directly increase the costs of audit firms who will reflect this in their prices which will then also increase the costs of the companies. This is also the reason why the Dutch government initially wanted to adopt mandatory internal auditor rotation rules (Ministerie van Financiën 2004, article 19). Start-up costs are generated by familiarization with the client's accounting procedures (Cameran et al. 2006). This is necessary in order to gain good knowledge of the client. As mentioned before, the knowledge the auditor had with the client over the years will be completely lost with the rotation of the audit firm.

Research among European accountant firms shows that their costs increases with 22.5 percent when they get a new audit client (Roos 2004). If an auditor is appointed in an area which is relatively new (where he is unfamiliar with) to him and his firm, the costs can even increase up to 50 percent 
(Arrunada\& Paz-Ares 1997). In the United States 96 percent of the Tier One Firms stated that their costs in the first year were higher than in the following years (GAO 2003). The clients on their turn have to provide resources for the auditor; they have to provide assistance and material resources. The client will spend more time to orient its new audit team. They will also make costs when selecting the new auditor; these are called research costs (GAO 2003). It causes extra costs and takes extra time. A study by Arrunada and Paz-Ares clearly shows how mandatory audit firm rotation increases the total audit costs. In their study they use a mathematical formula to predict the increases of costs that mandatory audit firm rotation rules would create. They took a hypothetical company with an indefinite duration that would change its audit firm. They analyze the difference in costs when a company switches its audit firm because of legal requirements instead of switching voluntarily. The results of their research are explained and can be found in the figure below (figure found in Arrunada and Paz-Ares 1997).

Table 1. Prior research survey on the impact of mandatory audit firm rotation on audit costs

\begin{tabular}{|c|c|c|}
\hline Author & Research & Results \\
\hline $\begin{array}{l}\text { Copeland ,2002 } \\
\text { Melancon ,2002 }\end{array}$ & $\begin{array}{l}\text {-What Do Practitioners Want? } \\
\text {-A new accounting culture: }\end{array}$ & $\begin{array}{l}\text { Mandatory audit firm rotation leads to an increase of total auditing costs for both the } \\
\text { auditors and companies. It will directly increase the costs of audit firms who will } \\
\text { reflect this in their prices which will then also increase the costs of the companies. }\end{array}$ \\
\hline Roos 2004 & $\begin{array}{l}\text { Roulatie van Accountants kantoor of } \\
\text { interne roulatie? }\end{array}$ & $\begin{array}{l}\text { Research among European accountant firms shows that their costs increases with } 22 \text {, } \\
5 \text { percent when they get a new audit client. }\end{array}$ \\
\hline $\begin{array}{l}\text { Arrunada and Candido } \\
\text { Paz-Ares, } 1995\end{array}$ & $\begin{array}{l}\text { Economic Consequences of } \\
\text { Mandatory Auditor Rotation. }\end{array}$ & $\begin{array}{l}\text { Mandatory audit firm rotation leads to an increase of total auditing costs up to } 50 \\
\text { percent. }\end{array}$ \\
\hline $\begin{array}{l}\text { Arrunada and Candido } \\
\text { Paz-Ares } 1997\end{array}$ & $\begin{array}{l}\text { Effect of mandatory audit firm } \\
\text { rotation on the audit costs and the } \\
\text { audit quality }\end{array}$ & $\begin{array}{l}\text { The research shows that the shorter the mandatory switching period is, the higher the } \\
\text { audit costs will be. It also shows that the costs will be higher if the company } \\
\text { estimated to switch over a longer period of time (for example } 40 \text { years) regardless of } \\
\text { the mandatory switching period. }\end{array}$ \\
\hline Blouin et al. 2005 & $\begin{array}{l}\text { An Analysis of Forced Auditor } \\
\text { Rotation: The Case of Former Arthur } \\
\text { Andersen Clients. }\end{array}$ & $\begin{array}{l}\text { Switching costs and agency benefits exist. Clients who did not follow their former } \\
\text { AA audit teams have less discretionary accruals after the rotation. Clients, who did } \\
\text { follow their former AA audit team, still had high levels of discretionary accruals. }\end{array}$ \\
\hline $\begin{array}{l}\text { Kwon, Kim \&Simnett, } \\
2010\end{array}$ & $\begin{array}{l}\text { Mandatory Audit Firm Rotation and } \\
\text { Audit Quality: Evidence from the } \\
\text { Korean Audit Market'. }\end{array}$ & $\begin{array}{l}\text { Korea, showing that audit hours as well as audit fees increased, whereas audit quality } \\
\text { (measured as abnormal discretionary accruals) remained unchanged or decreased } \\
\text { slightly. }\end{array}$ \\
\hline $\begin{array}{l}\text { United States General } \\
\text { Accounting Office, } \\
2003 \& 2004\end{array}$ & $\begin{array}{l}\text { Potential Effects of Mandatory Audit } \\
\text { Firm Rotation }\end{array}$ & $\begin{array}{l}\text { Initial year audit costs under mandatory audit firm rotation would increase by more } \\
\text { than } 20 \% \text { combined auditor selection costs and additional auditor support costs } \\
\text { totaling at least } 17 \% \text { of initial year audit fees. }\end{array}$ \\
\hline Barton, 2002 & $\begin{array}{l}\text { Analysis of the mandatory auditor } \\
\text { rotation debate }\end{array}$ & For being selected or kept as auditor, Italian firms are lowering their fees. \\
\hline $\begin{array}{l}\text { Azizkhani, Monroe \& } \\
\text { Shailer, } 2010\end{array}$ & $\begin{array}{l}\text { The value of Big } 4 \text { audits', } \\
\text { Accounting \& Finance }\end{array}$ & $\begin{array}{l}\text { Audit firm tenure is significantly associated with lower ex-ante cost of equity capital, } \\
\text { but only for non-Big } 4 \text { audit firms for the years } 1995-2005 \text {. However, for the periods } \\
2001-2002 \text { and } 2003-2005 \text {, audit firm tenure and engagement partner tenure are not } \\
\text { significantly associated with ex-ante cost of equity capital. }\end{array}$ \\
\hline
\end{tabular}

Various findings drawn from previous studies, together with what has been discussed above it can be indicated that most prior research was carried out in developed countries. Hence, there is a need to examine the impact of the MAR on audit costs in one of the emerging economies; kingdom of Bahrain. Based on the above discussion, the following hypotheses are formulated:

H01: There is no statistically significant relationship between mandatory audit firm rotation and audit costs.

H02: There are no significant differences between respondent group perceptions on the effects of mandatory audit firm rotation on the audit costs.

\subsection{Debate over the Mandatory Audit Firm Rotation}

There are some arguments within proponents and opponents for auditor rotation in partner and at firm's level. From the proponent's perspective, the first main argument is independence of auditors. They believe that with mandatory audit rotation, the independence of auditor increases and leads to high audit quality (Lennox, Wu, \&Zhang, 2014), thus it avoids and reduces audit failures (Casterella\& Johnston, 2013). Therefore, by recognizing the minimum and the maximum length of tenure, the auditor will be forced to pay attention to the details and be more skeptical in their audit approach. They believe that long tenure between auditor and client lead to excessive familiarity between them and impair independence of auditors (Casterella\& Johnston, 2013; Catanach Jr \&Walker, 1999; Firth, et al., 2012; Stefaniak, et al., 2009). Most analytical studies support a positive effect between auditor rotation and audit quality (Carcello\& Nagy, 2004; Daugherty, et al., 2013; Firth et al., 2012; Harris \&Whisenant, 2012). In contrast, the ombudsman of mandatory auditor rotation belief that in the extended term, the auditors are in close association with the company and in congruence with the board on reporting and the rotation of auditors would have a positive effect on audit quality (Ewelt-Knauer, et al., 2013).

Opponents of mandatory audit firm rotation have argued that the agency benefits will not outweigh the costs. The 
main perspective of opponents considers that cost of mandatory auditor rotation is more than its benefits such as set-up costs of new auditors to recognize the new client's model, losing of client-specific information and structure of the organization and also believe that audit partner rotation does not improve quality of audit where audit markets are highly focused with a handful of large audit firms controlling the market (Bandyopadhyay, et al., 2013). They believed that cost of audit firm rotation is in excess of audit partner rotation. The new audit firm brings a new audit team, as a result of audit firm rotation and also uses an extra new client procedure with new audit methodology. However, in audit partner level only the audit partner changes and new audit partner use and follow previous working papers, audit methodology and history of the firm related to the client (Chen, et al., 2008; Daugherty et al., 2013). Second perspective considers that audit fees will be enhanced when the mandatory auditor rotation occur because it forces the auditor and client relationship into a restricted period, so that they will enhance the audit's initial fees due to dearth of audit firm who are willing to offer low fees initially (Chi, 2005; DeAngelo, 1981). Also, the loss in the charm of audit profession isone of the negative features of audit firm rotation (KPMG LLP, 2010). In this situation, auditors concern about rising in indecisiveness relating to capacity of audit prerequisites and where to find best capable personnel with specific expertise (Ewelt-Knauer et al., 2013).

In addition to the increase in audit costs, there are other costs that should be taken into consideration. For example, once a firm is forced to rotate, the company must devote significant resources to identifying and hiring a new audit firm that has the requisite expertise. Such costs include meeting and corresponding with firms regarding the company's business, drafting and responding to proposals, and interviewing the audit firms. Once selected, the company would also need to devote significant time to educating the audit firm on the company's business and operations, internal control systems, accounting and financial reporting systems, and other areas so the firm has the requisite knowledge to perform a quality audit. In addition to the significant time involved in gaining the necessary understanding of the company's business, operations and systems, the audit firm must also devote considerable time to reviewing the predecessor auditor's working papers, identifying risk areas, understanding complex transactions and other audit planning matters that generally involve significant time commitments as part of the first year's audit. It is likely that these additional audit hours would result in an increase in audit fees to the company.

The supporters on the other hand argue that the agency benefits are worth the cost. However the 1000 public company in the United States believes that the costs of mandatory audit firm rotation are not worth the benefits. In the Government Accountability Office's (GAO) "Required Study on the Potential Effects of Mandatory Audit Firm Rotation," firms estimate that in the first year, mandatory firm rotation could result in increased audit costs of more than 20 percent 8 The GAO Study also estimated that "Following a change in auditor under mandatory audit firm rotation, the possible additional first year audit-related costs could range from 43 percent to 128 percent higher than the likely recurring audit costs had there been no change in auditor.'(See fig. 1.)

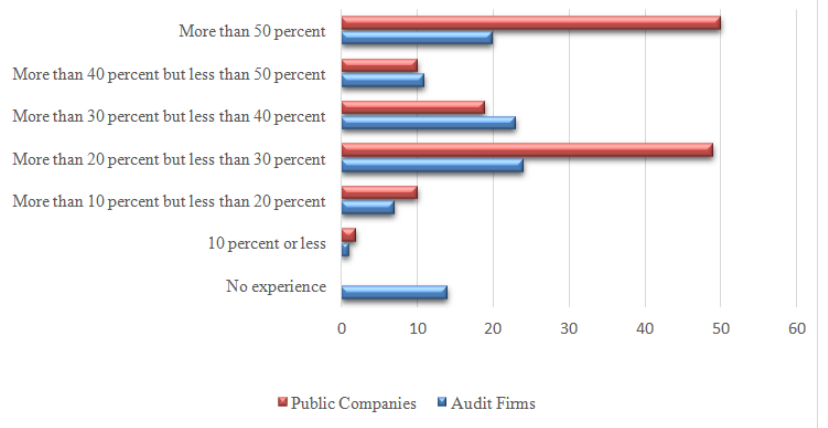

Figure 1. Expected Increase in Initial Year Audit Costs over Subsequent Year Audit Costs

\section{Research Methodology and Sample Characteristics}

The study used two sources of data collection: primary and secondary sources. The primary source of data is based on survey methods using questionnaires in order to gather the information related to this study. The benefit of using this method is that the researchers can contact participants who might be inaccessible (Cooper and Schindler, 2003). In addition, the data are collected using primary sources in order to gather the perceptions of the respondents. According to Cooper and Schindler, primary sources are always the most authoritative because the information has not been filtered or interpreted by a second party. Therefore, survey is one of the most appropriate methods used in collection of primary data. Secondary data on the other hand, are the information collected from official journals, articles, newspapers, text books and internet. Analyses of variance (ANOVA) were also conducted to determine whether auditors' perception of the impact of MAR on the auditor costs was influenced by demographic characteristics.

The questionnaire comprises three sections. Section one contains some demographic information and the current audit practices ; section two includes questions about potential effects of mandatory audit firm rotation upon audit independence, and section three composes questions about overall opinions on requiring mandatory audit firm rotation. The questionnaire was revised in the light of a feedback received from professionals who are working at universities and audit firms. Respondents were asked to express their opinions on the potential effects of mandatory audit firm rotation upon audit costs using a Liker Scale of five points ranging from 1 "strongly agree" to five "strongly disagree".

The data used in this study are obtained from a sample of auditors who are practicing in audit firms in Kingdom of 
Bahrain. Auditors are considered as entire authorized and approved individuals and not specific auditing firms. Also, the increasing use of the word auditors in our study does not by any means refer to both external and internal auditors. That is to say the word auditors in this study refer only to external auditors. We asked each auditing firm to provide us with the number of auditors who are qualified to fill the questionnaire, and the total number of auditors received from all auditing firms in Bahrain was 102. Accordingly, 102 questionnaires were distributed with a response rate of $64.7 \%$. (Appendix 1 contains a list of auditing firms in Bahrain).

\subsection{Reliability of Study Tool}

To proof the reliability of the study tool, we gave a copy of the questionnaire to many accounting professors in Bahrain University and other universities in Bahrain and outside Bahrain. The help provided by auditors from PWC and KPMG in Bahrain was sought in the design of the questionnaire. Also, the questionnaire is given to some academic professors who are specialized in statistics. All their notes and comments were taken in our consideration before we finalized the questionnaire.

\subsection{Internal Consistency of the Questionnaire Reliability}

Table 2. Reliability Statistics

\begin{tabular}{lll}
\hline \multicolumn{2}{l}{ Reliability Statistics } & \\
\hline Cronbach's Alpha & Cronbach's Alpha Based on & N of Items \\
& Standardized Items & 15 \\
\hline
\end{tabular}

The internal consistency of the questionnaire reliability was measured by using Cronbach's coefficient alpha statistical test as shown in Table 2 above. The analysis provides an indication of the average correlation among all the items that made up the scale. The study demonstrate that all indices obtained were considered high (0.769). A sample scale that shows alpha value above 0.70 is considered reliable (Bryman and Cramer, 2001). Therefore, the indices for the questionnaire reliability are generally considered adequate for this study.

\section{Statistical Analysis}

\subsection{Descriptive Analysis}

Descriptive analysis regarding demography variables is shown in Table 3 below:

Table 3. Respondents' distribution according to demography variables

\begin{tabular}{lll}
\hline Experience & Frequency & Percentage (\%) \\
\hline Less than 5 years & 24 & 36.4 \\
5 - less than 10 & 26 & 39.4 \\
10 - less than 15 & 8 & 12.1 \\
$15-20$ & 4 & 6.1 \\
More than 20 & 4 & 6.1 \\
Qualification & & \\
B.S.C. & 24 & 36.4 \\
Graduate degree & 12 & 18.2 \\
\hline
\end{tabular}

\begin{tabular}{lll}
\hline Experience & & \\
\hline & Frequency & Percentage (\%) \\
\hline CPA/CA/ACCA/CFA/CMA & 44 & 66.7 \\
Others & 2 & 3 \\
Company's auditor & & \\
BIG 4 & 24 & 36.4 \\
Non-BIG 4 & 42 & 63.6 \\
No. of employees & & \\
Up to 50 & 46 & 69.7 \\
Above 50 & 20 & 30.3 \\
\hline
\end{tabular}

It is shown from table 3 that $63.6 \%$ of the respondents have over 5 years' experience and this result indicates that the extent of experience and maturity may be reflected positively upon the work. The table also shows that the majority of the respondents $(66.7 \%)$ have professional certificate, followed by B.S.C. with $36.4 \%$ and graduate degree with $18.2 \%$. These results indicate highest academic level that respondents have, and this may be positively reflected upon the importance of the information given by the respondents. It is also noted from the analysis that $36.4 \%$ of the auditing offices are BIG 4 which means that the level of audit service provided by such offices is at high level.

Moreover, the table shows that the number of employees working in audit offices is 50 employees on average with $69.7 \%$ and $30.3 \%$ above 50 employees. This results indicate that the auditing offices are working very well and are established themselves in the market.

Table 4 below shows the distribution of respondents according to current audit practice. It is apparent from the analysis that the auditors provide services other than audit service to the client. The first service provided is accounting services $(97 \%)$ followed by internal audit service (75.8\%) then financial system design and implementation and legal service with $(54.5 \%)$ for each.

Table 4. Respondents' distribution according to current audit practices

\begin{tabular}{|c|c|c|c|c|}
\hline \multicolumn{5}{|c|}{ Services provided to audit clients (other than audit) } \\
\hline & \multicolumn{2}{|c|}{ Frequency (\%) } & \multicolumn{2}{|c|}{ Frequency (\%) } \\
\hline & yes & $\%$ & No & $\%$ \\
\hline $\begin{array}{l}\text { Financial system design and } \\
\text { implementation }\end{array}$ & 36 & 54.5 & 30 & 45.5 \\
\hline Taxation & 12 & 18.2 & 54 & 81.8 \\
\hline Accounting services & 64 & 97 & 2 & 3 \\
\hline Internal audit services & 50 & 75.8 & 16 & 24.2 \\
\hline $\begin{array}{l}\text { Management functions or human } \\
\text { resources }\end{array}$ & 26 & 39.4 & 40 & 60.6 \\
\hline Legal services & 36 & 54.5 & 30 & 45.5 \\
\hline Other non-audit services & 34 & 51.5 & 32 & 48.5 \\
\hline \multicolumn{5}{|c|}{$\begin{array}{l}\text { Does your company have a policy that requires the mandatory audit firm } \\
\text { rotation rules }\end{array}$} \\
\hline No. & 38 & & 57.6 & \\
\hline Yes & 10 & & 15.2 & \\
\hline No answer & 18 & & 27.3 & \\
\hline \multicolumn{5}{|c|}{$\begin{array}{l}\text { How many years should the mandatory firm be permitted to once again } \\
\text { compete for audit services }\end{array}$} \\
\hline Three to less than five years & 14 & & 21.2 & \\
\hline Five years to less than eight years & 8 & & 12.1 & \\
\hline Eight to ten years & 2 & & 3 & \\
\hline Greater than ten years & 2 & & 3 & \\
\hline No answer & 40 & & 60.6 & \\
\hline
\end{tabular}




\begin{tabular}{llll}
\hline \multicolumn{3}{l}{ Services provided to audit clients } & (other than audit) \\
\hline & \multicolumn{2}{l}{ Frequency (\%) } & \multicolumn{2}{l}{ Frequency (\%) } \\
\cline { 2 - 3 } & yes & \% & No \\
\hline Three to less than five years & 12 & 18.2 \\
Five years to less than eight years & 12 & 18.2 \\
Eight to ten years & 4 & 6.1 \\
Greater than ten years & 0 & 0 \\
No answer & 0 & 0 \\
Do you believe that mandatory firm's should be applied uniformly for \\
audits of all public companies regardless of the nature or size of the public \\
company \\
No & 2 & \\
Yes & 26 & 3 \\
No answer & 36 & 39.4 \\
\hline
\end{tabular}

Also, the results show that the majority of the respondents $(57.6 \%)$ do not require the mandatory audit firm rotation rule where as $15.2 \%$ of the respondents have a policy that require the mandatory audit firm rotation rule and $27.3 \%$ have no answer.

The table also indicates that the majority of the respondents $(60.6 \%)$ have no answer regarding the number of years that should the mandatory firm be permitted to once again compete for audit services followed by choice of three to less than five years and then five years to less than eight years.

The results regarding what should be the limit on the mandatory firm's audit tenure period also indicates that the choices "three to less than five years" and "five years to less than eight years" have $18.2 \%$ for each. Also the results regarding the statement "do you believe that mandatory firm's should be applied uniformly for audits of all public companies regardless of the nature or size of the public company" indicated that the respondents were not in agreement, in which $54.5 \%$ have no answer, $39.4 \%$ answer yes, and $3 \%$ answer No.

\subsection{Auditors' Perceptions on Effects of Audit Firm Rotation on Perceived Auditor Independence}

Table 5 below shows the means and standard deviations for each question individually and all questions together that test the hypothesis. The analysis indicates that the means range from 2.0- 3.36. This means that all the respondents reject the null hypothesis and accept the alternative hypothesis. The standard deviation range from .66 -.99 which means that there is agreement among respondent about the hypothesis and the variances are low since the standard deviation of any question is less than half of the related mean. The average mean for all questions together of the hypothesis equal 2.56 with standard deviation of .85 which is less than half of the mean. This indicates that there are no dispersion views among respondents about the questions of the hypothesis. Also, the analysis shows that the $\mathrm{t}$ value is (33.726) which is larger than the table critical value of $t$ (1.66), and the p-value is 0.000 which is less than the value of significance at $(\mathrm{p}<0.05)$. This result indicates that there is statistically a significant relationship, which means that the null hypothesis is rejected and accepted the alternative hypothesis, and that there is a statically significant correlation between mandatory rotation of external auditor and audit cost at value of significance $(p<0.05)$

Table 5. Means and standard deviation to the questions related to the hypothesis

\begin{tabular}{|c|c|c|c|c|c|}
\hline \multirow{2}{*}{ Question No. } & \multicolumn{5}{|l|}{ Audit cost } \\
\hline & Questions & Mean & Std. Deviation & t-Value & P-Value \\
\hline 1 & $\begin{array}{l}\text { The cost of marketing the Auditing process is the cost of what the audit offices } \\
\text { and firms exert to win new clients or retain the old ones. }\end{array}$ & 2.58 & .99 & 21.068 & 0.000 \\
\hline 2 & $\begin{array}{l}\text { The additional marketing costs that are likely to occur under mandatory audit } \\
\text { firm rotation will be passed on to public companies through higher audit fees. }\end{array}$ & 2.58 & .79 & 26.635 & 0.000 \\
\hline 3 & $\begin{array}{l}\text { The obligation of changing the external auditor will increase the cost incurred } \\
\text { by the Auditor at each change, because the start in Auditing from beginning } \\
\text { needs a lot of physical and moral effort to knew the transactions and account } \\
\text { systems of the new client. }\end{array}$ & 2.18 & .84 & 21.112 & 0.000 \\
\hline 4 & $\begin{array}{l}\text { The time spent by the auditor to know the accounting procedures applied by the } \\
\text { new client and be familiar with the system of his internal control will increase } \\
\text { the cost of the auditing process. }\end{array}$ & 2.00 & .78 & 20.712 & 0.000 \\
\hline 5 & $\begin{array}{l}\text { The potential cost that may results under mandatory rotation are likely to } \\
\text { significantly exceed the benefits. }\end{array}$ & 2.76 & .93 & 24.110 & 0.000 \\
\hline 6 & $\begin{array}{l}\text { Mandatory rotation will lead to increase the workload on the internal auditors } \\
\text { due to providing the necessary information for the new auditor. }\end{array}$ & 2.61 & .89 & 23.726 & 0.000 \\
\hline 7 & $\begin{array}{l}\text { Mandatory rotation will add cost of time and cost of choice of new auditor for } \\
\text { both management and the auditor. }\end{array}$ & 2.58 & .75 & 28.071 & 0.000 \\
\hline 8 & $\begin{array}{l}\text { Mandatory rotation will add additional costs for the company because the } \\
\text { amount of time management spends during the transition educating the new } \\
\text { auditor. }\end{array}$ & 2.5 & .66 & 30.495 & 0.000 \\
\hline 9 & $\begin{array}{l}\text { Mandatory rotation will lead to increase audit efficiencies and related higher } \\
\text { audit costs. }\end{array}$ & 3.15 & .86 & 29.645 & 0.000 \\
\hline 10 & Mandatory rotation will likely lead to lower audit fees and firm profitability. & 3.36 & .85 & 32.043 & 0.000 \\
\hline 11 & $\begin{array}{l}\text { It is believed that the difficulty of audits and the degree of complexity } \\
\text { associated with them have a significant impact in determining the audit fees. }\end{array}$ & 2.1 & .87 & 19.474 & 0.000 \\
\hline 12 & $\begin{array}{l}\text { It is believed that the changing the external auditor alleviate or eliminate the } \\
\text { competition in the market of auditing services leads to enhancing the objectivity } \\
\text { and the independence of the external auditor. }\end{array}$ & 2.42 & .96 & 20.478 & 0.000 \\
\hline
\end{tabular}




\begin{tabular}{|c|c|c|c|c|c|}
\hline \multirow{2}{*}{ Question No. } & \multicolumn{5}{|l|}{ Audit cost } \\
\hline & Questions & Mean & Std. Deviation & t-Value & P-Value \\
\hline 13 & $\begin{array}{l}\text { When a change in public accounting firm is voluntary, the new firm's additional } \\
\text { initial year audit costs are more likely to be absorbed by the firm and not passed } \\
\text { on to the public company in the form of higher audit fees because of the firm's } \\
\text { interest in retaining the audit client. }\end{array}$ & 2.61 & .89 & 23.726 & 0.000 \\
\hline 14 & $\begin{array}{l}\text { Firms will be more likely to increase audit fees during the new limited audit } \\
\text { tenure period to increase the likelihood of recovering any additional initial year } \\
\text { audit costs incurred to fully understand the public company's operations and } \\
\text { financial reporting practices. }\end{array}$ & 3.36 & .82 & 23.534 & 0.000 \\
\hline \multirow[t]{2}{*}{15} & $\begin{array}{l}\text { The lower audit fees likely to occur from increased opportunities to compete } \\
\text { under mandatory audit firm rotation will likely result from increased audit } \\
\text { efficiencies and related lower audit costs. }\end{array}$ & 2.57 & .78 & 26.635 & 0.000 \\
\hline & Average mean \& standard deviation for all second hypothesis questions together & 2.56 & .85 & 33.726 & 0.000 \\
\hline
\end{tabular}

T-distribution with 65 degree of freedom, for level of significance of .05, the table critical value is 1.66.

\subsection{Auditors' Perceptions of Importance of Mandatory Audit Rotation}

Table 6 below indicates the opinions of the respondents regarding requiring mandatory audit firm rotation. The analysis indicates that $45.5 \%$ believe that audit firm rotation would enhances auditor quality, independence and objectivity and should be implemented, $36.4 \%$ believe that it can work if rotation period is long enough, whereas $12.1 \%$ believes that the benefits of mandatory audit firm rotation would exceed the costs of implementing such a requirement.

Table 6. Respondents' distribution according to overall opinions on requiring mandatory audit firm rotation

\begin{tabular}{|c|c|c|c|}
\hline \multirow{2}{*}{ Answer No. } & \multicolumn{3}{|l|}{ There should be compulsory rotation of audit firm after a fixed number of years } \\
\hline & & Frequency & Percentage $(\%)$ \\
\hline 1. & $\begin{array}{l}\text { Yes, I believe it enhances auditor quality, independence and objectivity and should be } \\
\text { implemented. }\end{array}$ & 30 & 45.5 \\
\hline 2. & Yes, it can work if rotation period is long enough. & 24 & 36.4 \\
\hline 3. & $\begin{array}{l}\text { No, the benefits of mandatory audit firm rotation would exceed the costs of implementing } \\
\text { such a requirement. }\end{array}$ & 8 & 12.1 \\
\hline \multirow[t]{2}{*}{4.} & No answer. & 4 & 6.1 \\
\hline & $\begin{array}{l}\text { Regarding your public company's (or firm's) overall current opinion on whether or not you } \\
\text { rotation of registered public accounting firms }\end{array}$ & ompany supp & ring mandatory \\
\hline 1 & $\begin{array}{l}\text { The company (firm) supports requiring mandatory rotation of public accounting firms at } \\
\text { this time provided that the period of time for rotation is reasonable. (Please provide the } \\
\text { principal reason for supporting mandatory rotation below.) }\end{array}$ & 22 & 33.3 \\
\hline 2 & $\begin{array}{l}\text { The company (firm) supports the concept of requiring mandatory rotation, but believes } \\
\text { more time is needed to evaluate the effectiveness of the various requirements of the } \\
\text { Sarbanes-Oxley Act of } 2002 \text { for enhancing audit quality. }\end{array}$ & 14 & 21.2 \\
\hline 3 & $\begin{array}{l}\text { The company (firm) does not support requiring mandatory rotation of public accounting } \\
\text { firms. (Please provide the principal reason for not supporting mandatory rotation below.) }\end{array}$ & 4 & 6.1 \\
\hline 4 & No answer & 26 & 39.4 \\
\hline
\end{tabular}

Regarding your public company's (or firm's) overall current opinion on whether or not your company supports requiring mandatory rotation of registered public accounting firms, the table shows that $33.3 \%$ of the respondents supports requiring mandatory rotation of public accounting firms at this time provided that the period of time for rotation is reasonable., $21.2 \%$ believes that the company (firm) supports the concept of requiring mandatory rotation, but believes more time is needed to evaluate the effectiveness of the various requirements of the Sarbanes-Oxley Act of 2002 for enhancing audit quality and $6.1 \%$ believes that the company (firm) does not support requiring mandatory rotation of public accounting firms.

Question 14 required respondents to make other comments in respect of mandatory rotation of auditors as they deem fit. One partner indicated mandatory partner rotation is "clearly a trade between independence and quality. Other stated that's "There is no doubt that rotation results in a loss of knowledge and, along with that, an ability to see signs of risk." One respondent viewed a cost of partner rotation as "a loss of industry knowledge that goes against the intent of the new risk assessment standards [designed] to gain an enhanced understanding of clients' business." Others believed that human capital costs to be the biggest cost of rotation including, "personnel turnover, family distress, illness, relocation, travel, and longer decision-making time on client questions and issues. Learning time is increased and leads to more early retirements." We can see that the results of table 5 are consistent table 6 results and provide clear pictures about the perceptions of audit firms in Bahrain regarding audit costs.

\subsection{Auditors' Background Variables and Perceptions of MAR and Audit Costs}

A one-way ANOVA was conducted to determine whether auditors' perceptions of the impact of MAR on the audit costs were influenced by demographic characteristics. The results 
of the tests are presented in table 7 below.Decision Rule: $F$ Calculated $>$ F Critical - Reject the Null Hypothesis.

Table 7 shows that respondents' positions did not have any significant impact on the perceptions of audit costs since the $\mathrm{F}$ Calculated $<\mathrm{F}$ Critical, and the $\mathrm{p}$ value $>.05$ for all statements. It was also found that experience has a significant impact on auditors' perceptions on some statement related to the impact of the MAR on the audit costs at (statements 5, $6,9,12$ and 13 with F Calculated $>$ F Critical and $p<.05$ ). The results also reveal that perceptions of auditors' were not affected by respondents' qualifications only for statement 5 (the F Calculated $>$ F Critical, and $\mathrm{p}<.05$ ). Furthermore, it was found that type of audit firm has no impact on auditors' perceptions of the impact of MAR upon the audit costs (F Calculated $<\mathrm{F}$ Critical, and the $\mathrm{p}$ value $>.05$ for all statements). There for the null hypothesis 'There is no significant differences between respondent group perceptions on the effects of mandatory audit firm rotation on the audit costs, is accepted only for the respondents' experience variable (statements 5, 6,9,12 and 13), whereas qualifications variable (statement 5 ) is rejected .

Table 7.Analysis of differences in perceptions of mandatory audit firm rotation and audit costs with demographic variables

\begin{tabular}{|c|c|c|c|c|c|c|c|c|c|}
\hline \multirow{2}{*}{$\begin{array}{l}\text { Question } \\
\text { Number }\end{array}$} & \multirow{2}{*}{ Questions } & \multicolumn{2}{|c|}{ Position } & \multicolumn{2}{|c|}{ Experience } & \multicolumn{2}{|c|}{ Qualification } & \multicolumn{2}{|c|}{ Audit Firm } \\
\hline & & $\mathbf{F}$ & $\begin{array}{l}\text { p- } \\
\text { value }\end{array}$ & $\mathbf{F}$ & p-value & $\mathbf{F}$ & p-value & $\mathbf{F}$ & p-value \\
\hline 1 & $\begin{array}{l}\text { The cost of marketing the Auditing process is the cost of what the } \\
\text { audit offices and firms exert to win new clients or retain the old } \\
\text { ones. }\end{array}$ & 0.866 & 0.445 & 1.822 & 0.146 & 2.098 & 0.143 & 0.824 & 0.462 \\
\hline 2 & $\begin{array}{l}\text { The additional marketing costs that are likely to occur under } \\
\text { mandatory audit firm rotation will be passed on to public } \\
\text { companies through higher audit fees. }\end{array}$ & 0.957 & 0.411 & 2.445 & 0.063 & 1.778 & 0.192 & 0.701 & 0.515 \\
\hline 3 & $\begin{array}{l}\text { The obligation of changing the external auditor will increase the } \\
\text { cost incurred by the Auditor at each change, because the start in } \\
\text { Auditing from beginning needs a lot of physical and moral effort } \\
\text { to knew the transactions and account systems of the new client. } \\
\text { The time spent by the auditor to know the accounting procedures }\end{array}$ & 0.971 & 0.404 & 2.298 & 0.031 & 2.550 & 0.092 & 0.861 & 0.447 \\
\hline 4 & $\begin{array}{l}\text { The time spent by the auditor to know the accounting procedures } \\
\text { applied by the new client and be familiar with the system of his } \\
\text { internal control will increase the cost of the auditing process. }\end{array}$ & 0.524 & 0.605 & 1.565 & 0.208 & 1.765 & 0.194 & 0.529 & 0.662 \\
\hline 5 & $\begin{array}{l}\text { The potential cost that may results under mandatory rotation are } \\
\text { likely to significantly exceed the benefits. }\end{array}$ & 1.518 & 0.258 & $4.028^{*}$ & $0.009 *$ & $4.184 *$ & $0.023 *$ & 1.423 & 0.279 \\
\hline 6 & $\begin{array}{l}\text { Mandatory rotation will lead to increase the workload on the } \\
\text { internal auditors due to providing the necessary information for } \\
\text { the new auditor. }\end{array}$ & 1.194 & 0.337 & $2.971 *$ & $0.033^{*}$ & 2.991 & 0.062 & 1.069 & 0.374 \\
\hline 7 & $\begin{array}{l}\text { Mandatory rotation will add cost of time and cost of choice of new } \\
\text { auditor for both management and the auditor. }\end{array}$ & 0.951 & 0.413 & 2.518 & 0.057 & 2.523 & 0.095 & 0.878 & 0.440 \\
\hline 8 & $\begin{array}{l}\text { Mandatory rotation will add additional costs for the company } \\
\text { because the amount of time management spends during the } \\
\text { transition educating the new auditor. }\end{array}$ & 0.646 & 0.541 & 1.767 & 0158 & 1.654 & 0.217 & 0.601 & 0.564 \\
\hline 9 & $\begin{array}{l}\text { Mandatory rotation will lead to increase audit efficiencies and } \\
\text { related higher audit costs. }\end{array}$ & 1.01 & 0.393 & $2.862 *$ & $0.036^{*}$ & 2.435 & 0.102 & 0.834 & 0.458 \\
\hline 10 & $\begin{array}{l}\text { Mandatory rotation will likely lead to lower audit fees and firm } \\
\text { profitability. }\end{array}$ & 1.194 & 0.337 & 2.422 & 0.061 & 3.218 & 0.051 & 1.123 & 0.357 \\
\hline 11 & $\begin{array}{l}\text { It is believed that the difficulty of audits and the degree of } \\
\text { complexity associated with them have a significant impact in } \\
\text { determining the audit fees. }\end{array}$ & 0.951 & 0.413 & 2.554 & 0.055 & 2.986 & 0.065 & 0.975 & 0.405 \\
\hline 12 & $\begin{array}{l}\text { It is believed that the changing the external auditor alleviate or } \\
\text { eliminate the competition in the market of auditing services leads } \\
\text { to enhancing the objectivity and the independence of the external } \\
\text { auditor. }\end{array}$ & 1.871 & 0.345 & $5.828 *$ & $0.001 *$ & 2.986 & 0.062 & 1.785 & 0.209 \\
\hline 13 & $\begin{array}{l}\text { When a change in public accounting firm is voluntary, the new } \\
\text { firm's additional initial year audit costs are more likely to be } \\
\text { absorbed by the firm and not passed on to the public company in } \\
\text { the form of higher audit fees because of the firm's interest in } \\
\text { retaining the audit client. }\end{array}$ & 1.165 & 0.352 & $3.264^{*}$ & $0.022 *$ & 3.097 & 0.056 & 0.849 & 0.452 \\
\hline 14 & $\begin{array}{l}\text { Firms will be more likely to increase audit fees during the new } \\
\text { limited audit tenure period to increase the likelihood of recovering } \\
\text { any additional initial year audit costs incurred to fully understand } \\
\text { the public company's operations and financial reporting practices. }\end{array}$ & .286 & .571 & 1.590 & 0.199 & 1.535 & 0.244 & 0.525 & 0.604 \\
\hline 15 & $\begin{array}{l}\text { The lower audit fees likely to occur from increased opportunities } \\
\text { to compete under mandatory audit firm rotation will likely result } \\
\text { from increased audit efficiencies and related lower audit costs. }\end{array}$ & 1.655 & .378 & 2.548 & 0.351 & 3.019 & 0.061 & 0.982 & 0.403 \\
\hline & F Critical & 3.885 & & 2.621 & & 3.238 & & 3.885 & \\
\hline
\end{tabular}




\section{Summary, Conclusions, and Limitations}

This study aimed to explore the perceptions of auditors on vexed issue of mandatory audit rotation of audit firms in Kingdom of Bahrain (audit costs). It is believed that this study would supplement literature by providing answers to the following research questions. 1) Does mandatory audit firm rotation influence auditor cost? And 2) to what extent the auditors' perceptions about the impact of mandatory audit firm rotation on the auditor audit costs influenced by demographic characteristics. Data for the study were collected by distributing an administered questionnaire to the sample study that consist all auditors working in audit firms in Bahrain. The study started by asking auditors the most basic question: Does your company have a policy that requires the mandatory audit firm rotation rules? 57.6 percent of the respondents 'indicated that they don't have such a policy. Nearly 40 percent of the respondents agreed with the statement that mandatory firm's should be applied uniformly for audits of all public companies regardless of the nature or size of the public company with audit tenure period of three to less than eight years. As a contribution to previous research, the perceived effects of mandatory audit firm rotation on audit costs found in this study was compared with the perceived effects found in previous studies by the first hypothesis. The Average mean and standard deviation for all first hypothesis questions together resulted in rejection to the null hypothesis. This means that there is a statistically significant relationship between mandatory audit firm rotation and audit costs by this study and that coincide by finding of prior studies (listed in table 1). The average mean of all questions together of the hypothesis is 2.56 with average standard deviation of .85 which is less than half of the mean. This indicated that there is no dispersion existed among respondents about the questions of the hypothesis. Also, the analysis shows that the $t$ value is (33.726)which is greater than the table critical value of $t$ (1.66), and the pvalue obtained is 0.000 which is less than the value of significance at $(p<0.05)$, these results confirm that there is a statistically significant relationship between audit firm rotation and audit costs. In order to contribute to previous studies on audit firm rotation, this study investigates auditors'opinions on requiring mandatory audit firm rotation. 45.5 percent of the respondents believe that mandatory audit firm rotation would enhance auditor independence and should be implemented. Moreover $36.4 \%$ of the respondents see it works if rotation period is long enough. Respondents were also asked their overall opinion on "whether or not your company supports requiring mandatory rotation of registered public accounting firms", $33.3 \%$ of the respondents indicated agreement on this issue. While only $6.1 \%$ believes it's not.

Another relevant question addressed by this study is to what extent the auditors' perceptions of the impact of mandatory audit firm rotation on the audit costs is influenced by demographic characteristics? Analysis of variance (ANOVA) was conducted to answer this question. As shown in Table 7it was found that respondents' positions do not have any significant impact upon the perceptions of audit costs .It was found also that experience has a significant impact on auditors' perceptions on some statement related to the impact of the MAR on the audit costs at (statements 5,6,9,12and 13).

The researchers concluded that the adoption of rotation rules wasn't given enough attention among the auditing firms in Bahrain. For that, $27.3 \%$ of respondents' don't know "whether their company have a policy that requires the mandatory audit firm rotation rules". $60.6 \%$ don't know how many years the mandatory firm should be permitted to once again compete for audit services. In asking the respondents their beliefs regarding whether MAR should be applied uniformly for audits of all public companies regardless of the nature or size of the public company, $54.5 \%$ indicate no answer. Also $39.5 \%$ of respondents' don't know "whether or not their company supports requiring mandatory rotation of registered public accounting firms.

The results of the study should be interpreted in the light of the limitations of the study. First the study is limited to Bahrain .The findings from the study can be generalized only to this group. Future studies could be useful to investigate the perceptions of other users such as institutional and private investors, audit committees and members of regulatory bodies. Second, although the respondents are offered opportunity to add any further thoughts, we may not be too sure what informed their judgment when they were rating the significance of the merits/demerits of mandatory rotation of audit costs. Third, findings of such a study may not be generalized to different countries at different stages of development or with different business environments and cultures. A comparative study of MAR practice for different countries with emerging capital markets might also be fruitful. Therefore, it would be interesting to replicate this study in other GCC countries or Middle Eastern countries. Fourth, the results are based on a limit number of respondents, we cannot assume that the views of nonrespondents are similar to the study findings. However, variables other than those included in the study may affect the mandatory audit rotation on costs. Despite these limitations, the researchers believe that this study has added to our understanding of the factors that encourage the demand for mandatory rotation of auditors in Bahrain. Our work should also inform the current global debate on whether mandatory rotation of audit firms will influence audit costs from the view point of emerging economies.

\section{Acknowledgment}

We thank an anonymous reviewer and the helpful comments and suggestions on an earlier draft of this paper made by many of our colleagues at the University of Bahrain. 


\section{Appendix 1}

\section{Listed Audit Firms in Bahrain}

KPMG Fakhro

Ernst \& Young

Deloitte \&Touche Bahrain

PricewaterhouseCoopers

PKF Bahrain

Horwath Bahrain

Moore Stephens International Ltd

National Audit Office

Grant Thornton

Talal Abu-Ghazaleh\& Co

BDO Jawad Habib

Assure Consulting WLL

Abdulaal Gulf Audit

Al Mezan Bureau

Al-Mudhaffar Public Accountants

HLB R. Yassa\& Co (N \& Co) Chartered Accountants

Nabeel Al Saie - Public Accountants

Jawad Habib \& Co

Dynamic Structures

Accounting \& Auditing Organization for Islamic Financial

Institutions

Raafat Yassa\& Co Chartered Accountant

Saba \& Co

El Sayed El Ayouty\& Co

Xpress Accounting - Bahrain

$\mathrm{Al}$ atheer Audit and Consulting

\section{References}

[1] AICPA (American Institute of Certified Public Accountants), (1992), "Statement of position regarding mandatory rotation of audit firms of publicly held companies".

[2] Arrunada, B. and Paz-Ares, C., (1997), "Mandatory rotation of company auditors: a critical examination", International Review of Law and Economics, 17(1), pp. 31-61.

[3] Bandyopadhyay, S. P., Chen, C., \& Yu, Y., (2013), Mandatory audit partner rotation, audit market concentration, and audit quality: Evidence from China. Advances in Accounting.

[4] Barton, Marquita Toinette, (2002), "Analysis of the Mandatory Auditor Rotation Debate", University of Tennessee Honors Thesis Projects. http://trace.tennessee.edu/utk_chanhonoproj /512.

[5] Breeden R. (2012),'Proposals for auditor independence and audit firm rotation", Available at: blogs.law.harvard.edu/.../2012/.../proposals-for-auditorindependence.

[6] Bryman, A. \& Cramer, D. (2001), Quantitative Data Analysis with SPSS Release 10 for Windows, London: Routledge.

[7] Cameron, M.; Prencipe A; and M. Trombetta, (2008), "Earnings management, auditor Tenure and Auditor Change: Does mandatory auditor rotation really improve audit quality?" Working Paper, Universita Boncconi.
[8] Carcello, J. V., \& Nagy, A. L., (2004), Audit firm tenure and fraudulent financial reporting. Auditing: A Journal of Practice \& Theory, Vol. 23, No. (2), pp. 55-69.

[9] Casterella, J. R., \& Johnston, D., (2013), Can the academic literature contribute to the debate over mandatory audit firm rotation? Research in Accounting Regulation, Vol. 25, No. (1), pp. 108-116.

[10] Catanach Jr, A. H., \& Walker, P. L., (1999), The international debate over mandatory auditor rotation: A conceptual research framework. Journal of International Accounting, Auditing and Taxation, Vol. 8, No. (1), pp. 43-66.

[11] Central Bank of Bahrain (CBB) Rulebook (1973), Volume 5, Auditors and Accounting Standards Module.

[12] Chen, C. Y., Lin, C. J., \& Lin, Y. C., (2008), Audit Partner Tenure, Audit Firm Tenure, and Discretionary Accruals: Does Long Auditor Tenure Impair Earnings Quality?*. Contemporary Accounting Research, Vol. 25, No. (2), pp. 415445 .

[13] Chi, W., (2005), The Effect of Mandatory Audit-Firm Rotation: A Monitoring Perspective. Research in Accounting Regulation, Vol.18 (Complete), pp. 283-285.

[14] Cooper D. R. and Schindler P. S., (2003), Business research methods, (8 Ed), New York, McGraw-Hill.

[15] Consumer Federation of America (CFA) (2011), 'PCAOB Release No. 2011-006, Docket Matter No. 37- Concept Release on Auditor Independence and Audit Firm Rotation', $<$ http://pcaobus.org/Rules/Rulemaking/Docket037/484_CFA.p df $>$, accessed 10/8/2012.

[16] Copeland, T. E., (2002), "What Do Practitioners Want?", Journal of Applied Finance. Vol. 12: p. 5-12.

[17] Daugherty, B. E., Dickins, D., Hatfield, R. C., \& Higgs, J. L., (2013), "Mandatory audit partner rotation: perceptions of audit quality consequences". Current Issues in Auditing, Vol. 7, No. (1), pp30-35.

[18] DeAngelo. L. E. (1981), “Auditor size and audit quality”, Journal of Accounting and Economics Vol.3, No. (1), pp. 167-175.

[19] Dopuch, N.; R. King; and R. Schwartz (2001), “An experimental investigation of retention and rotation requirements", Journal of Accounting Research, Vol. 39, pp. 93-118.

[20] Ewelt-Knauer, C., Gold, A., \&Pott, C., (2013), "Mandatory audit firm rotation: A review of stakeholder perspectives and Prior Research", Accounting in Europe, Vol. 10, No. (1), pp. $27-41$.

[21] Elliott, R.K. and Jacabson, P., (2000), "Audit independence: Concept and Application", The CPA Journal, Vol. 62, No. 3, pp. 34-3.

[22] Ernst \& Young (2011), 'PCAOB Rulemaking Docket Matter No. 37 - Concept Release on Auditor Independence and Audit FirmRotation', <http://pcaobus.org/Rules/Rulemaking/Docket 037/063_EY.pdf $>$, accessed 10/8/2012.

[23] European Commission (2011b), "Study on the effects of the implementation of the "acquis" on statutory audits of annual and consolidated accounts including the consequences on the auditmarket', $<$ http://ec.europa.eu/internal_market/auditing/do cs/studies/201111-summary_en.pdf $>$, accessed 30/8/2012. 
[24] European Commission (2011a), 'Reforming the Audit MarketFrequentlyAskedQuestions', <http://europa.eu/rapid/pressRele asesAction.do?reference $=$ MEMO $/ 11 / 856 \&$ format $=$ HTML\&ag ed $=0$ \&language $=E N \&$ guiLanguage $=e n>$, accessed 10/8/2012.

[25] Firth, M.; Rui, O. M.; and Wu, X. (2012), "How do various forms of auditor rotation affect audit quality? Evidence for China”, The International Journal of Accounting, Vol.47, No. (1), pp. 109-138.

[26] General Accounting Office (GAO), (2003), "Required study in the potential effects of mandatory audit firm rotation". Report to the Senate Committee on Banking, Housing, and Urban Affairs and the House Committee on Financial Services, Washington, DE: GAO.

[27] Government Accounting Office (GAO) (2008), “Continued concentration in audit market for large public companies does not call for immediate action", Available at: http://www.gao.gov/products/GAO-08-163.

[28] Harris, K., \&Whisenant, S., (2012), Mandatory Audit Rotation An International Investigation. University of Houston.

[29] Healy, PM, Palepu KG (1993), "The effects of firms' disclosure strategies on stock prices", Accounting Horizons, Vol. 7, No. 1, pp. 1-11.

[30] Horwath C. (2012), "Audit firm rotation- A good or bad proposal, April 9. Available at: www.crowehorath.net/...horwath.../audit_firm_rotation_agood...

[31] Institute der Wirtschaftsprüfer (IDW) (2012b), 'Reform must serve audit quality: IDW submission to the German government regarding the European system for audits,pressrelease1/2012', <http://www.idw.de/idw/download/ Presseinfo 12012 englisch.pdf?id=615074\&property=Datei $>$, accessed $10 / 8 / 20 \overline{1} 2$.

[32] Jensen, M. C., Meckling, W. H. (1976), 'Theory of the firm: Managerial behavior, agency costs and ownership structure', Journal of Financial Economics, Vol. 3, pp 305-360.

[33] Kim, J.-B. And Yi, C. H., (2009), "Does auditor designation by the regulatory authority improve audit quality? Evidence form Korea”, Journal of Accounting and Public Policy, Vol.28, No. (3), pp. 207-230.

[34] KPMG, Audit committee Institute- EC Audit Reform, KPMG, Oct., 2010. www.kpmg.com/global/en/services/audit/eu-auditreform/documents/aci-audit-reform.pdf

[35] Krishnan, J., and Krishnan, J. (1996), 'The role of economic trade-offs in the audit opinion decision: An empirical analysis", Journal of Accounting, Auditing, and Finance, Vol.11, (Fall), pp. 565-586.

[36] Kwon K.Soo.; Lim Y. D.; and Simmnett R. (2010), "Mandatory audit firm rotation and audit quality: Evidence from the Koorean audit market", Available at; www.asb.unsw.edu.au/../..Lim\%2020\%Mandatory\%20Audit\%20Firm
[37] Lennox, C. S.; Wu, XI, and Wang X. (2014), "Does mandatory rotation of audit partners improve audit quality?", Accounting Review, Vol. 89, No. 5, Sept., pp. 1775-1804.

[38] Lev, B. (1992), "Information disclosure strategy", Calif. Manage. Review, Vol. 34, No. 4, pp. 9-32.

[39] Melancon, B.C., (2002), A new accounting culture: A speech made by President and CEO of the American Institute of CPAs to the Yale Club in New York.

[40] Ministerie van Financiën, (2004), Wet toezicht accountant sorganisaties [Voorstel van Wet], Den Haag, juni, Nederland.

[41] PCAOB (Public Company Accounting Oversight Board) (2011), "Concept release on auditor independence and audit firm rotation (PCAOB Release No. 2011-009", August 16, 2001; PCAOB Rulemaking Docket Matter 37), Available at: http://pcaobus.org/Rules/Rulemaking/Docket037/Release_201 1-006.pdf.

[42] Pierre, K. St and J. Anderson (1984), "An analysis of the factors associated with lawsuits against public accountants", The Accounting Review, Vol. 59, pp. 242-263.

[43] Price Waterhouse (2012), "Mandatory audit firm rotation point of view", Available at: www.pwc.com/us/en/poins-ofview/mandatory-audit-firm-rotation.

[44] Roos, R., (2004), "Roulatie van accountant skantoren of interne roulate", MaandbladVoor Accountancy en Bedrijfseconomie. November: p. 472-

[45] Sarbanes-Oxley Act of 2002, Public Law 107-204, 107th Cong., 2nd sess. 24 July.

[46] Schipper, K. and L. Vincent, (2003) 'Earnings Quality,' Accounting Horizons, Vol.17, Supplement.

[47] Shockley, RA., (1981), "Perceptions of Auditors' Independence: An Empirical Analysis", the Accounting Review, No. 4, pp. 785-800.

[48] Stefaniak, C., J. C. Robertson, and R. W. Houston (2009), "The causes and consequences of auditor switching: A review of the literature". Journal of Accounting Literature, Vol. 28, pp. $47-121$.

[49] Teoh, S. H., and T. J., Wong, (1993), "Perceived auditor quality and the earnings response coefficient", The Accounting Review, (April): pp. 346-366.

[50] The Conference Board Commission on Public Trust and Private Enterprise - findings and recommendations, (2008). www.conference-board.org/pdf_free/SR-03-04.pdf

[51] United States General Accounting Office, 2003, GAO - 03 1173, Washington, D. C.

[52] Watts, R. L. and Zimmerman, J. L., (1986), Positive Accounting Theory, Prentice-Hall, Upper Saddle River, New Jersey 